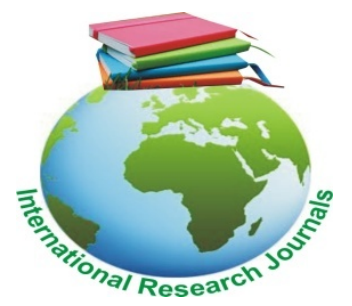

Educational Research (ISSN: 2141-5161) Vol. 7(2) pp. 041 -054, April, 2016

Available online@ http://www.interesjournals.org/ER

DOI: http:/dx.doi.org/10.14303/er.2016.127

Copyright (c) 2016 International Research Journals

Full Length Research Paper

\title{
Factors Influencing Stress among Public Secondary School Female Principals in Kenya: A case study of Rachuonyo North and Homa Bay Sub-Counties
}

\author{
Jane K. A Juma ${ }^{1}$, ${ }^{*}$ Enose M.W. Simatwa ${ }^{1}$, Theodore M.O. Ayodo ${ }^{2}$ \\ ${ }^{1}$ Department of Educational Management and Foundations, Maseno University \\ ${ }^{2}$ Faculty of Education, Arts and Theology, Kabarak University \\ ${ }^{*}$ Corresponding Author's Email:simatwae@yahoo.com
}

\begin{abstract}
Principals play a pivotal role in performance of students in secondary schools. In many instances, this calls for high professional and societal demands, and expectations. As a result, principals experience stress. Studies in countries like USA, Britain, Norway, India, Nigeria and Kenya have revealed that optimal stress among principals enhances students' performance in public examinations while excessive stress reduces students' performance. In Rachuonyo North and Homa Bay Sub counties, the mean scores for schools headed by female principals from 2010 to 2014 were 3.77 and 4.20 respectively compared to those headed by male principals whose mean scores were 5.05 and 5.67 for the same period. These performances were below those of Rachuonyo South Sub County which were 4.67 for female principals and $\mathbf{5 . 2 0}$ for male principals for the same period. The performances of schools headed by female principals' were lower than those headed by male principals. These studies have linked stress among principals to students' performance. The purpose of this study was to establish factors influencing stress among public secondary school female principals in public secondary schools in Rachuonyo North and Homa Bay Sub counties, Kenya. This study established that female principals in Rachuonyo North and Homa Bay Sub counties were experiencing moderate stress at a mean (M) 3.37 and Standard Deviation (SD) 1.290 on a 5 -point scale. Stress factors accounted for $\mathbf{5 2 . 9 \%}$ of female principals stress levels. The factors that had highest influence on stress levels of female principals were working environment ( $M$ 3.67, $S D=1.287)$, pursuit for excellence $(M=3.65$, $S D=1.033)$, conflicting demands from stakeholders $(M=3.68), S D=1.156)$, lack of time to teach and attend to administrative tasks $(M=3.373, S D=1.122)$, workload $(M=3.54, S D=1.260)$, uncertainty in job expectations $(M=3.97, S D=1.166)$, undisciplined teachers $(M=3.58, S D=1.357)$ and staff shortage $(M$ $=3.78, \mathrm{SD}=1.357$ ).
\end{abstract}

Keywords: Factors, stress, Public Secondary School Female Principals, Rachuonyo North, Homa Bay Sub Counties, Kenya

\section{INTRODUCTION}

The government of Kenya is concerned with the global agenda of achieving education for all. The academic performance of students has become a great concern to stakeholders of education. This has led the government to formulate and implement policies to improve academic performance. Stress has also been found to be a major contributing factor to academic performance. Robins
(2001) states that optimal level of stress can enhance learning ability. However too much stress can cause physical and mental health problems and may affect the academic achievement of students.

Boyland (2011) in a study on job stress and coping strategies of elementary principals; a statewide study in USA found out that a large majority of Indiana's 
elementary principal participants were experiencing moderate to high levels of job stress. In addition, most of the experienced principals indicate more stress now than previous years. A total of 193 principals from 79 counties in Indiana responded to the survey. This was a return rate of $67 \%$ and represents $86 \%$ of the counties in the state of Indiana. However, the studies did not indicate study population, instruments of data collection and research methodology, therefore very hard to verify the accuracy of the results. This study focused on factors influencing stress among female principals in public secondary school in Rachuonyo North and Homa-Bay Sub counties; however the study did not address factors influencing stress among female principals, a gap that current study seeks to fill. Stamper and Johlke (2003) first introduced the idea of stress into the life of science. They defined stress as the force, pressure or tension subjected upon an individual who resists these forces and attempts to uphold its true state. Pressure is seen as positive and something that actually helps to improve our performances which therefore mean persons need a certain amount of pressure to perform well. However, the problem then arise when the sources of pressure become too frequent without time to recover, or when just one source of pressure is too great for individuals to cope with.

In Kenya, Ngari et al (2013), in their study on levels of stress among secondary school administrators and its implication in education management in Kenya established that the school administrators experience stress in their work. Fifty four point five percent of the respondents recorded high levels of stress resulting from their school workload and other responsibilities. Among the three administrative levels of stress compared to deputies and heads of departments. Ngari et al (2013) focused on stress among administrators in general but this study narrowed down to female principals.

Stress at work place is a worldwide issue. A report on secondary education by World Bank (1999) revealed that the education systems in the world-over had been ineffective and had failed to address the matter of principals' stress and burnout in secondary schools. This failure however has stifled natural efforts towards building a stronger human resource base which is invaluable for development in all its spheres in schools. Studies carried out in developed countries such as Canada and France have indicated that the employees working in educational institutions especially the high school principals and their deputies reported high levels of stress related illness. However these studies did not address factors influencing stress among female principals in relation to students' performance, a knowledge gap that the current study sought to fill. In the developing countries, Kenya inclusive, similar sentiments of secondary school principals exhibits stress related issues. A study in Ghana showed that teachers and educational administrators are experiencing series of stress and stressful situations (Schroeder et al., 2001). Koome (2007) who carried out a study in Kenya among principals found that principals stress is on the increase such that most of them have dropped being principals due to stress and have joined other departments in the government like the Ministry of Education's Quality Assurance and Standards Officer / County Directors or as Teachers Service Commission Directors and also the Ministry of Youth Affairs, Gender and Sports among others. The studies reviewed reveal that principals of schools experience stress. These studies however have not addressed issues on factors influencing stress among public secondary school female principals in Homa Bay County.

The inevitable reforms in the education system calls upon school principals in developing and developed world to stringently raise the level of their school agenda, commitments and actions and be continually dissatisfied with the status quo and dream of a brighter future. More than ever, the school principals are expected to manage their school finances properly, ensure the school excels in academics and co-curricular activities, meet political agenda and other societal expectations. Regrettably, the school principals are put under intense pressure to perform well beyond their capability.

Occupational stress levels are on the increase across many professions. According to research by Johnson et al (2005), intense pressure to perform may lead to burnout and hence have a negative impact on an organization and the individual. In the context of public secondary schools, the principals are put under pressure especially during national examinations, Form 1 selection and the release of Kenya Certificate of Secondary Education results. The principals are judged depending on their performance and their careers may be on the line. In fact, such huge expectations and possibility of rash judgment negatively impact on of an individual.

Stress in the workplace has been observed in various professional; For instance, employees in the medical field have been known to work under intense conditions (Travers and Cooper, 1994). Several studies have been carried out globally concerning - stress in the workplace but the major emphasis has been on industry and business sectors, In Kenya, some research has been done on issues of stress in the educational sector. However, stress levels, factors, influence and reaction among public secondary female school principals in Homa-bay County had not been addressed.

In Nigeria, Olayiwola (2008) in his study on dimensions of job stress among public secondary school principals in Oyo State concluded that public secondary school principals are experiencing job stress in the same dimensions. The reasons are that sources of this job stress are related to administrative routines, inability to delegate, conflicting demands from Ministry and workload. Olayiwola (2008) focused on dimensions of job 
Table 1: Number of Schools and Principals Leaving due to Stress 2003-2013

\begin{tabular}{|c|c|c|c|c|c|c|c|c|c|c|c|}
\hline \multirow[t]{2}{*}{ County } & \multicolumn{6}{|c|}{ School Type and Number } & $T$ & \multicolumn{2}{|c|}{$\begin{array}{l}\text { Principals who left } \\
\text { Principal ship due } \\
\text { to stress }\end{array}$} & \multirow{2}{*}{$\begin{array}{l}\text { Female } \\
\% \\
\text { F } \\
\end{array}$} & \multirow{2}{*}{$\begin{array}{l}\text { Male \% } \\
\text { M }\end{array}$} \\
\hline & MD & MDB & BB & $B / D$ & G/B & GB/D & $\mathbf{T}$ & $\mathbf{F}$ & $\mathbf{M}$ & & \\
\hline Rachuonyo North & 25 & 6 & 2 & 2 & 5 & 5 & 45 & 11 & 07 & $24.44 \%$ & $15.56 \%$ \\
\hline Rachuonyo South & 39 & 10 & 3 & 7 & 7 & 4 & 70 & 17 & 07 & $24.29 \%$ & $10.00 \%$ \\
\hline Homa Bay & 37 & 7 & 5 & 0 & 4 & 0 & 53 & 15 & 13 & $28.30 \%$ & $24.53 \%$ \\
\hline Ndhiwa & 20 & 5 & 4 & 2 & 3 & 4 & 38 & 13 & 08 & $34.21 \%$ & $21.05 \%$ \\
\hline Suba & 10 & 5 & 2 & 0 & 2 & 1 & 20 & 07 & 06 & $35.00 \%$ & $30.00 \%$ \\
\hline Mbita & 21 & 3 & 4 & 1 & 3 & 2 & 34 & 12 & 07 & $35.29 \%$ & $20.59 \%$ \\
\hline Total & 152 & 36 & 20 & 12 & 24 & 16 & 260 & 75 & 48 & 28.85 & 18.46 \\
\hline
\end{tabular}

Source: TSC Director County Office- Homa Bay - 2013

Key: MD- Mixed Day MDB - Mixed Day Boarding BB-Boys Boarding T- Total F = Female

B/D- Boys Day G/B- Girls Boarding GB/D - Girls Boarding and Day M - Male

stress among public secondary school principals in Oyo State. The study used descriptive survey research design. The study also used cluster sampling to select the sample size. The instrument used was a 40-item questionnaire tagged: Dimensions of Job Stress for Principal Questionnaire. The questionnaire was adapted from Payne and Furnham (1987) and Nhundu (1999) instruments. The study sample was 100 principals from all 937 public secondary schools. However, this sample size is too small to represent the study population. This therefore means the findings may not appropriately represent the study population. The research design was appropriate.

In Kenya, in a study on investigating high school principals' stress in relation to their job experience in schools in Southern Nyanza region of Kenya revealed that the sources of stress: role based, task based, conflict mediating and boundary spanning had a correlation and dependable relationship with high school principals' job experience in schools (Yambo et al., 2012). Yambo et al (2012) focused on investigating high school principals' stress in relation to their job experience in schools in southern Nyanza region of Kenya. They used descriptive survey. The study was guided by Role Performance and Demand theory by Hebb (1972). Stratified random sampling technique was used to select the sample. The current study used descriptive and corelational research designs. Simple random sampling and purposive sampling technique was used to select the sample size. Rating scales was used to analyze the data. Yambo et al (2012) did not investigate on school factors causing stress among female principals per se.

In Kenya and particularly Rachuonyo North and Homa-bay Sub counties, female principals are stressed and some of them have opted to quit principalship and teaching profession all together (Teachers Service Commission Director County Office, Homa-Bay, 2013).

Table 1 shows that $75(28.85 \%)$ female principals left due to stress compared to $48(18.46 \%)$ male principals. This means that more female principals left principalship than male principals; hence the need for a study on stress levels among public secondary school female principals and its influence on students' performance.

\section{Objective of the Study}

To determine Factors Influencing Stress among Public Secondary School Female Principals in Rachuonyo North and Homa Bay Sub Counties, Kenya.

\section{Synthesis of literature on factors that influence stress among female principals}

Causes of stress in the school system have been Identified in numerous earlier studies and yet there are continuing reports that stress is increasing (De Nobile and McCormick, 2005). Stress is a psychological and physiological response to events that upset our personal balance. The potential causes of stress are numerous. It may be linked to the outside factors such as the state of the world; environment in which one lives or works or the family. It may come from one's own irresponsible behavior, negative attitudes or feeling or unrealistic expectation. The causes of stress are highly individual; it depends on the personality, general outlook on life, problem solving abilities, and social support system. Many different things causes stress from physical to emotional, identifying what causes stress is the first step to deal with stress.

One of the stressors among public school Female principals is professional demands. In the Kenyan public school system, the functions of managing and administering the school fall on the principal, who is 
assisted by the Deputy Principal and others such as the Senior Master and Mistress. The school principal and his/her deputy are custodians of an enterprise comprising considerable investment of resources in terms of finances, facilities and human skills. They are expected to preside over and manage the entire school. Being important persons in the school system, they have the overall task of managing the schools by ensuring balanced academic programmes and proper supervision of work as well as effective leadership. The ability of high school managers to withhold, contain and contend with the various school responsibilities, challenges and functions largely depend on their capacity and capability (Nhundu, 1999).

Heavy workload and time pressures are part of the occupational challenges that principals go through. For school principals to be able to function effectively, they have to be able to perform several functions that demand them to be not only experienced, but competent in these duties. The expectations on them necessitate that they supervise the delivery lines and activities of their individual schools. As much as possible, they are to create a very conducive atmosphere that would allow for maximum attainment of school goals and objectives and the education as a whole. The environment within which they operate cannot be free of problems that are typical of a populous African nation with a high demand for education. Some of these problems include over population of students; problems with the school structures; ill- equipped and inadequate principals to cope with the workload; students with poor academic backgrounds; poor funding that effects management; students negative attitude towards learning; parental ambivalence towards the educational well - being of their children; low motivation; low performance and overall lackadaisical attitudes of principals towards work; personal problems including role conflict; societal problems and pressings; financial problems; domestic worries; and a lot more (Pithers and Soden, 2002).

The school Female principals in Rachuonyo North and Homa-bay Sub counties, Kenya are not immune to all these problems. Against all these odds, the school principals are expected to be competent professionals in their duties, Principals and students as well as parents and other stakeholders, look up to them to meet up with their various needs. They are to manage the meager resources at their disposal to attain results. They are also to promote useful and profitable interaction of minds within the school community through various media; thus bringing about the needed mutual confidence is pooling experiences for effective problem solving, They are similarly to establish an atmosphere that will ensure effective management of the curriculum and its application to students' needs, aims, objectives and aspirations of the immediate environment and the nation. (MacPherson, 1985).

As leaders, they are seen as those whose examples transcend their precepts at work, play, in the office/school. They show examples by patience, amicability, kindness, consideration and genuineness interest for their students. Hoyle (1989) points out that, the role of the school principal is charged and overloaded with expectations to the point at which if the school principals were to meet them all, they risk burnout. Also, Ajayi (1995) alluded to this fact about the expectations of the school principal as an executive. This makes the school principal vulnerable to stress which may be mild or major, depending on environmental factors as well as the personality of the individual executive. As those who have to make things work in the organization, they cannot be exposed to a lot of stressful events. Like all formal organizations, the school system has specific administrative tasks and functions.

Interpersonal relationships are also a factor causing stress among school principals. Working with people can be a source of support or stress. The complexities of life, both private and organizational have made stress to be an inevitable thing in their lives. The individual at work is always faced with some form of difficulty or painful experiences and which results in stress that could be a damaging factor to the individual's productivity, which is a challenging motivator. Learners' performance is a major cause of stress among principals. Students' failure is often viewed as failure on the part of principals which may lead to stress (Hughes, 2001). Parents' pressure causes principals to experience stress. Parents' attitude towards principals is a most disturbing factor and principals feel that they do not receive the necessary support and appreciation from parents and the community hence this is a hindrance to learning. Changes in family values and mental Status also greatly impact upon principals' stress (Thomas, Clarke and Lvery, 2003). Principals often have to nurture, counsel and be a mother or father to certain learners due to family work factors or divorce. Almost any aspect of the job environment is capable of producing stress. Occupational stress remains one of the major causes of premature death world-over. As a result, clinical and health psychologists are increasingly becoming involved with clients identified as high risk group individuals either formally as part of preventive programme or informally through contact with general practitioners.

According to a review by the Department of Health and Human Services, 1988 there are approximately 110 million workers in the United states who are exposed to a wide variety of occupational hazards that can pose significant risks to their health and most of which are stress related. Similarly life style stressors contribute greatly, more than environmental, biological and other festers to premature death. A World Health Organization report stated that, about one half of the entire working population are unhappy in their jobs and as many as $90 \%$ may be spending much of their energy and time in work that brings them no closer to their goals in life. About 
Juma et al., 045

\section{Independent Variables}

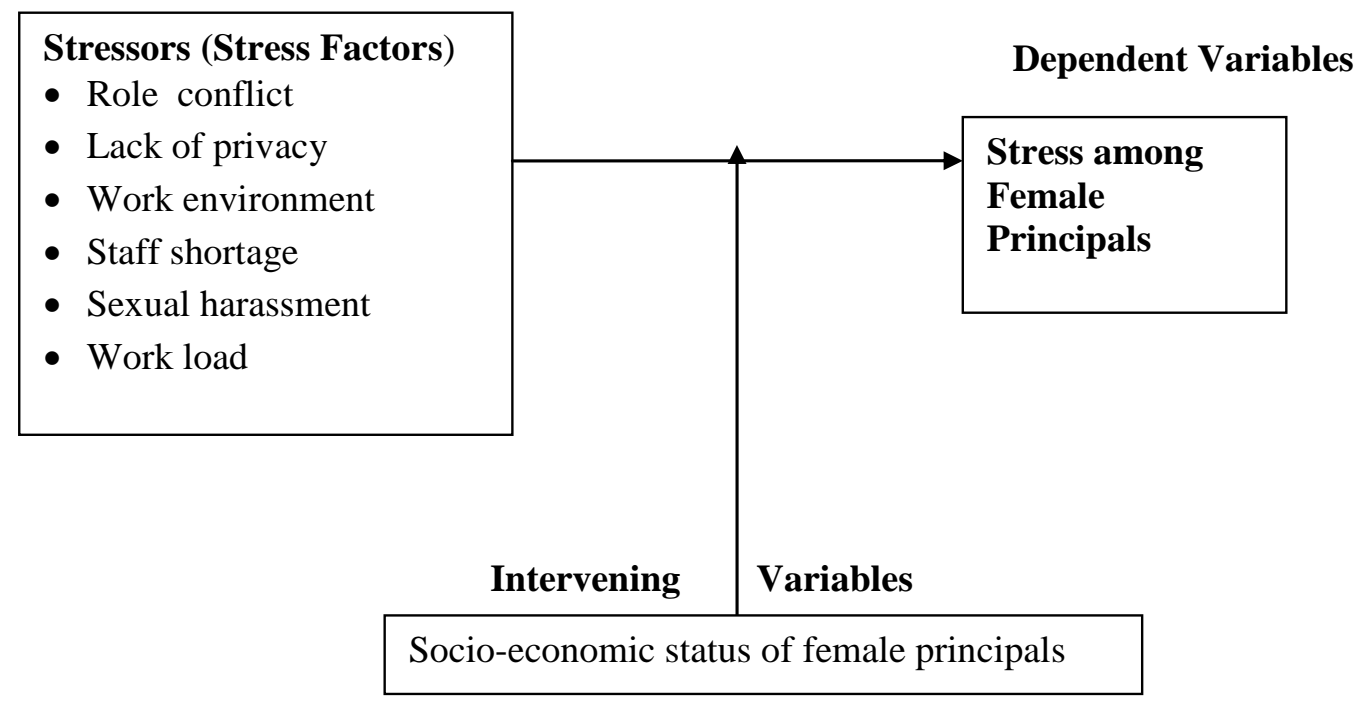

Figure 1: A conceptual framework showing factors influencing stress among public secondary school female principals

$75 \%$ of those who consult psychiatrists are experiencing problems that can be traced on job satisfaction, or inability to unwind (Levi, 1987). The Swedish Government Commission for Work Environment and Health Report, 1990 submitted that there are adverse conditions of work among professionals. A common and possibly decisive denominator of these work conditions is that which expose workers to a combination of high psychosocial stress and physical work load and a low level of decision latitude (Karasek and Theorell, 1990).

The teaching profession, of which school principals and deputy principals as managers belong, can rightly be said to be seen as one stressful job. This is evident in the overwhelming frustrating situations within which they function in Rachuonyo North and Homa-bay Sub counties. As such therefore, many sources of stress can as well be identified in their job. As pointed out in the foregone submissions, principals and vice principals as school managers, are prone to complain about a variety of somatic concerns (De Nobile and McCormick, 2005). In an era of globalization and reform agenda in education, the leadership to be provided by them is extremely important. But they can unfortunately be overwhelmed by conflicting expectations that had become associated with their role within the educational community. Reviewed studies tend to focus on factors that influence stress in general.

\section{Conceptual framework}

The study was guided by a conceptual framework (Figure 1) which postulates that there are factors that influence stress among female principals.

The conceptual framework shows the relationship between independent variables (stressors) and dependent variable (stress among female principals) in public secondary schools and the intervening variable is the socio-economic status of female principals. The factors that are bound to influence stress among female principals may include role conflict, lack of privacy, work environment, sexual harassment, political interference, undisciplined teacher, workload, lack of time to teach and administer, staff shortage among others. The influence may be moderated by socio-economic status of female principals. The conceptual framework helped the researchers to focus on the variable of the study.

\section{RESEARCH METHODOLOGY}

Descriptive survey and correlational research designs used were adopted. The study population consisted of 43 female Principals, 43 Deputy Principals, 80 Heads of Department, 43 Board of Management chairpersons and 2 Sub County Quality Assurance and Standards Officers. Fisher's formula was used to determine sample size. Saturated sampling technique was used to select 2 Sub County Quality Assurance and Standards Officers while simple random sampling technique was used to select 39 Principals, 39 Deputy principals, 72 Head of Departments and 39 Board of Management chairpersons. Questionnaire, interview schedules and document analysis guide were used to collect data. Face and content validity of the instruments was determined by experts in Educational Administration whose input was 
Table 2: Demographic Characteristics of Female Principals $(n=43)$

\begin{tabular}{|c|c|c|}
\hline Demographic characteristics & Frequency (f) & Percentage (\%) \\
\hline \multicolumn{3}{|l|}{ Gender } \\
\hline Female & 39 & 100 \\
\hline \multicolumn{3}{|l|}{ Age } \\
\hline $31-40$ & 5 & 12.8 \\
\hline $41-50$ & 25 & 64.1 \\
\hline $51-60$ & 9 & 23.1 \\
\hline Total & 39 & \\
\hline \multicolumn{3}{|l|}{ Highest level of Education } \\
\hline Diploma in Education & 1 & 2.6 \\
\hline Bachelors Degree & 27 & 69.2 \\
\hline Masters degree & 10 & 25.6 \\
\hline Doctor of Philosophy Degree & 1 & 2.6 \\
\hline Total & 39 & 100 \\
\hline \multicolumn{3}{|c|}{ Headship Experience in current schools } \\
\hline $1-5$ & 20 & 51.2 \\
\hline $6-10$ & 12 & 30.8 \\
\hline $11-15$ & 4 & 10.3 \\
\hline $16-20$ & 1 & 2.6 \\
\hline $21-25$ & 2 & 5.1 \\
\hline Total & 39 & 100 \\
\hline \multicolumn{3}{|c|}{ Headship Experience in other schools } \\
\hline 0 & 25 & 00.0 \\
\hline $1-5$ & 5 & 35.8 \\
\hline $6-10$ & 9 & 64.3 \\
\hline Total & 39 & 100 \\
\hline \multicolumn{3}{|l|}{ Teaching experience } \\
\hline $6-10$ & 6 & 15.4 \\
\hline $11-15$ & 16 & 41.0 \\
\hline $16-20$ & 10 & 25.6 \\
\hline $21-25$ & 5 & 12.8 \\
\hline $26-30$ & 2 & 5.1 \\
\hline Total & 39 & 99.9 \\
\hline
\end{tabular}

incorporated to make them valid. Reliability of the instrument was determined by test re-test approach whereby a correlation coefficient of 0.7 and above would be considered reliable at a $p$ - value of 0.05 . The reliability coefficient for the questionnaire was 0.84 , meaning it was reliable. Quantitative data was analyzed using frequency counts, means, percentages; and regression analysis while qualitative data was analyzed for content in emergent themes and sub themes.

\section{RESULTS}

From Table 2, the ages of female principals were 31-40 years, $5(12.8 \%) ; 41-50$ years, $25(64.1 \%)$ and 51-60 years, $9(23.1 \%)$. This means that majority of female principals were middle aged. The highest levels of academic qualification were as follows: Diploma in
Education 1(2.3\%); Bachelors Degree 27(69.2\%); Masters Degree 10(25.6\%) and Doctor of Philosophy 1(2.6\%). Headship experience in the current schools: $1-5$ years 20(51.2\%); 6-10 years, $12(30.8 \%)$; $11-15$ years, $4(10.3 \%)$ and $21-25$ years, 2(5.1\%). Headship experience in other schools was as follows: 1-5 years $5(35.8 \%)$ and $6-10$ years, $9(64.2 \%)$ and 25 female principals did not have experience in other schools. Teaching was as follows: 6-10 years, 6(15.4\%); 11-15 years, $16(41.0 \%)$; $16-20$ years, 10 (25.6\%); $21-25$ years, $5(12.8 \%)$ and $26-30$ years, 2(5.1\%). These descriptive statistics reveal that female principals' responses were authentic and realistic in terms of factors influencing their stress.

From Table 3, it can be noted that 35(89.7\%) schools were located in rural areas while $4(10.3 \%)$ in urban areas. 
Table 3: School Data

\begin{tabular}{lcc}
\hline Location & Frequency $(\mathbf{F})$ & Percentage (\%) \\
\hline Rural & 35 & 89.7 \\
Urban & 4 & 10.3 \\
Total & 39 & 100 \\
Number of Teachers per School & & \\
$1-5$ & 10 & 25.6 \\
$6-10$ & 11 & 28.2 \\
$11-15$ & 9 & 23.1 \\
$16-20$ & 5 & 12.8 \\
$21-25$ & 2 & 5.1 \\
$26-30$ & 2 & 5.1 \\
Total & 39 & 99.9 \\
Enrolment & & \\
$50-89$ & 5 & 12.8 \\
$90-121$ & 9 & 23.1 \\
$130-169$ & 6 & 15.4 \\
$170-209$ & 7 & 17.9 \\
$210-249$ & 3 & 7.7 \\
$250-289$ & 3 & 5.1 \\
$290-329$ & 2 & 0 \\
$330-369$ & 0 & 2.6 \\
$370-401$ & 1 & 2.6 \\
$410-449$ & 1 & 7.7 \\
$450-489$ & 3 & 2.6 \\
$490-529$ & 1 & 2.6 \\
Total & 1 & 100.1 \\
\hline
\end{tabular}

The descriptive statistics revealed that $21(53.8 \%)$ had 1 to 10 teachers; $14(35.9 \%) ; 11$ to 20 teachers and $4(10.2 \%) 21$ to 30 teachers. This means that most schools were understaffed. This may translate to high stress among female principals as the demands from teachers, parents, Ministry of Education Science and Technology and students may be overwhelming. Student enrolments varied highly as follows: $14(35.9 \%)$ had enrolments of 50 t o 121 students; 13(33.3\%) 122 to 169 students; 5(12.8\%) 170 to 249 students and 7(17.9\%) 250 to 529 students. The descriptive statistics reveal that most of these schools (69.2\%) were not cost-effective in financing. This translates to high stress among school managers as the demands from students, teachers and parents can hardly be met to high satisfaction.

\section{Research Question}

The research question responded to was: what factors influence stress among public secondary school female principals? The responses were as shown in Table 4. In order to respond to this research question, first stress levels of principals were determined using a 5-point rating scale.
From Table 4, it can be observed that 20 (51.28\%) female principals were established to be experiencing low stress levels as their means ranged from 1.45 to 2.44 . Thirteen (33.33\%) were established to be experiencing moderate stress with a mean range of $2.45-3.44$ while $6(15.38 \%)$ while female principals were experiencing high levels of stress. Overall, female principals in Rachuonyo North and Homa Bay Sub counties were established to be experiencing moderate stress with a mean rate of 2.95 .

In response to the research question the female principals rated factors influencing their stress levels from 2011 to 2014 on a 5 - point rating scale and the results were as shown in Table 5. The interpretation of the ratings were that: one (1) meant that the factor had very low influence; (2) meant that the factors had low influence, (3) meant that the factor had moderate influence, (4) meant that the factor had high influence and (5) meant that the factor had very high influence .

For interpretation of means, mid-points in the five point scale were used to generate the scale as follows:
$1: 00-1.44$
Very low influence
$1: 45-2.44$
Low influence
$2: 45-3.44$
Moderate influence
$3: 45-4.44$
High influence 
048 Educ. Res

Table 4: Stress Levels of Female Principals in Rachuonyo North and Homa-bay Sub counties

\begin{tabular}{|c|c|c|}
\hline$S / N$ & Mean & Std. Deviation \\
\hline 1 & 2.60 & 1.19 \\
\hline 2 & 2.95 & 1.47 \\
\hline 3 & 2.50 & 1.40 \\
\hline 4 & 3.90 & 1.33 \\
\hline 5 & 3.10 & 1.17 \\
\hline 6 & 3.20 & 1.44 \\
\hline 7 & 3.24 & 0.44 \\
\hline 8 & 3.35 & 1.42 \\
\hline 9 & 3.05 & 1.28 \\
\hline 10 & 2.90 & 0.97 \\
\hline 11 & 3.00 & 1.30 \\
\hline 12 & 2.05 & 0.97 \\
\hline 13 & 2.86 & 1.41 \\
\hline 14 & 1.90 & 0.91 \\
\hline 15 & 2.37 & 0.83 \\
\hline 16 & 1.70 & 1.38 \\
\hline 17 & 3.40 & 1.35 \\
\hline 18 & 3.45 & 0.69 \\
\hline 19 & 2.90 & 1.83 \\
\hline 20 & 4.05 & 1.32 \\
\hline 21 & 2.40 & 1.35 \\
\hline 22 & 4.05 & 1.31 \\
\hline 23 & 3.45 & 1.39 \\
\hline 24 & 1.74 & 0.65 \\
\hline 25 & 2.90 & 1.12 \\
\hline 26 & 2.95 & 1.15 \\
\hline 27 & 2.85 & 1.18 \\
\hline 28 & 4.60 & 0.60 \\
\hline 29 & 2.58 & 0.77 \\
\hline 30 & 2.75 & 1.83 \\
\hline 31 & 4.15 & 0.81 \\
\hline 32 & 2.90 & 1.29 \\
\hline 33 & 2.85 & 1.14 \\
\hline 34 & 1.45 & 0.69 \\
\hline 35 & 3.05 & 0.69 \\
\hline 36 & 2.00 & 1.15 \\
\hline 37 & 3.00 & 1.26 \\
\hline 38 & 3.00 & 1.70 \\
\hline 39 & 3.80 & 1.11 \\
\hline Overall Mean & 2.95 & 1.16 \\
\hline
\end{tabular}

4:45 - 5.00 Very High influence

The instrument used was adapted from that of Martha, Elizabeth and Mathew (1988)
The adaptation involved tailoring them into Kenyan situation based on the day to day experiences of principals in their operations. 
Juma et al., 049

Table 5: Factors influencing stress among Public Secondary School Female Principals

\begin{tabular}{lcc}
\hline Factors /Female Principals life events & Mean & Standard Deviation \\
\hline a) Role conflict & 3.30 & 1.222 \\
b) lack of opportunities for career development & 3.22 & 1.336 \\
c) Lack of privacy & 3.06 & 1.494 \\
c) Working environment & 3.67 & 1.287 \\
d) Undisciplined teachers & 3.58 & 1.131 \\
e) Political interference & 3.40 & 1.288 \\
f) Pursuit for excellence & 3.65 & 1.033 \\
g) Increased participatory management & 3.03 & 1.301 \\
h) Increased use of ICT & 3.32 & 1.532 \\
i) Conflicting demands from stakeholders & 3.68 & 1.156 \\
j) Lack of time to teach and administer & 3.73 & 1.122 \\
k) Lack of office space for self and staff & 3.17 & 1.404 \\
L) Staff shortage & 3.78 & 1.357 \\
m) Sexual harassment & 2.54 & 1.643 \\
n) Poor communication & 3.00 & 1.269 \\
o) Inadequate support from stakeholders & 3.27 & 1.427 \\
p) Lack of opportunity for promotion & 3.19 & 1.151 \\
q) Work load & 3.54 & 1.260 \\
r) Uncertainty job in expectations & 3.97 & 1.166 \\
Overall Mean & 3.37 & 1.29 \\
\hline
\end{tabular}

Interpretations of Level of Influence:

1.00-1.44 = Very Low Influence; 1.45 -2.44 = Low Influence; 2.45 -3.44 = Moderate Influence;

3.45 -4.44 = High Influence and $4.45-5.0=$ Very High Influence

Table 6: Relationship between factors influencing stress and levels of stress among female principals

\begin{tabular}{lcc}
\hline & & Stress \\
\hline Factors influencing & Pearson Correlation & .728 \\
stress & Sig. (2-tailed) & .000 \\
& $\mathrm{~N}$ & 39 \\
\hline
\end{tabular}

Pearson Product-Moment Correlation ( $r$ ) was computed to establish the influence of principals' life events (factors) on their levels of stress. In order to determine the influence, the null hypothesis: "There is no statistically significant relationship between female principals' life events (factors) and their levels of stress" was generated and the results were as shown in Table 6.

From Table 6 it can be noted that there was a strong positive correlation between factors influencing stress and levels of stress among principals. This was signified by Pearson's $r$ coefficient of .728 as the calculated $p$ value of .000 was less than the set $p$-value of .05 . The null hypothesis "principalship life events have no influence on stress levels of female principalships in Rachuonyo North and Homa-bay Sub counties was rejected. The factors that had high influence included uncertainty job expectations such as time for disbursement of Free Secondary education funds, quality of Kenya Certificate of Secondary Examination results, fee defaulters $(M=3.97, \quad S D=1.166)$, staff shortage $(M=3.78, \quad S D=1.357)$, lack of time for teaching and administration $(M=3.73, S D=1.122)$, conflicting demands $(M=3.68, S D=1.156)$, pursuit for excellence in Kenya Certificate of Secondary Examination ( $M=3.65$, SD $=1.033)$, supervision of undisciplined teachers $(M=3.58$, $\mathrm{SD}=1.131$ ) and work environment $(\mathrm{M}=3.67, \mathrm{SD}=1.287)$.

The factors that had moderate influence included; sexual harassment $(M=2.54, S D=1.643)$, opportunity for promotion $(M=3.19, S D=1.51)$, lack of support from fellow teachers, sponsors, school managers and job security $(M=3.27, S D=1.427$ ), poor communication in the schools $(M=3.00, S D=1.269)$, lack of office space for principals and staff $(M=3.17, S D=1.404)$, increase in use of ICT $(M=3.32, \quad S D=1.532)$ participatory management $(M=3.03, S D=1.301)$, political distractions $(3.40, S D=1.288)$, lack of privacy $(M=3.06, S D=1.494)$, 
Table 7: Coefficient of determination of factors influencing stress among female principals

\begin{tabular}{lcccc}
\hline Model & $\mathbf{R}$ & $\mathbf{R}$ Square & Adjusted R Square & Std. Error of the Estimate \\
\hline 1 & $.728^{\mathrm{a}}$ & .529 & .516 & .4922646 \\
\hline
\end{tabular}

a. Predictors: (Constant), factors influencing stress

Table 8: Analysis of Variance of factors and stress among female principals

\begin{tabular}{lcccccc}
\hline Model & & Sum of Squares & df & Mean Square & F & Sig. \\
\hline 1 & Regression & 9.814 & 1 & 9.814 & 40.500 & $.000^{\mathrm{b}}$ \\
& Residual & 8.724 & 36 & .242 & & \\
& Total & 18.538 & 37 & & & \\
\hline
\end{tabular}

a. Dependent Variable: Female principals stress level

b. Predictors: (Constant), factors influencing stress

Table 9: Linear Regression Analysis of Stress factors and female principals levels of stress

\begin{tabular}{|c|c|c|c|c|c|c|}
\hline \multirow[b]{2}{*}{ Model } & & \multicolumn{2}{|c|}{ Unstandardized Coefficients } & \multirow{2}{*}{$\frac{\text { Standardized Coefficients }}{\text { Beta }}$} & \multirow[b]{2}{*}{$\mathbf{t}$} & \multirow[b]{2}{*}{ Sig. } \\
\hline & & B & Std. Error & & & \\
\hline 1 & (Constant) & .553 & .385 & & 1.438 & .159 \\
\hline & Factors influencing stress & .709 & .111 & .728 & 6.364 & .000 \\
\hline
\end{tabular}

a. Dependent Variable: stress level

Regression equation $Y=a+b X$

lack of career development $(\mathrm{M}=3.22, \mathrm{SD}=1.336)$ and role conflict $(\mathrm{M}=3.30, \mathrm{SD}=1.222)$.

To determine influence of these factors on female principals' levels of stress regression analysis was done and the results were as shown in Table 7 .

From Table 7 it can be noted that factors influencing stress among female principals accounted for $52.9 \%$ of the variation in levels of stress among female principals. The other $47.1 \%$ could have been due to other factors that were not investigated by this study. This means that the identified principals' life events or factors were critical in determining the female principals' stress.

To determine whether Free Secondary Education was a significant predictor of access, ANOVA was computed. The results were as shown in Table 8.

From Table 8 it can be observed that factors influencing stress levels among female principals in Rachuonyo North and Homa Bay sub counties were significant predictors of stress levels among principals. This meant that these factors can be relied upon in prediction of stress levels among principals. Thus principals' experiencing such life events over a period of time can lead to a stress level of a given magnitude.

To determine the actual effect or influence linear regression analysis was performed and the results shown in Table 9. From Table 9, it can be observed that increase in one unit of factors that influence stress would lead to increase in stress level by 0.709 as signified by the coefficient 0.709 units. The regression equation is: $\mathrm{Y}=0.553+0.709 \mathrm{X}$

\section{DISCUSSION}

School principals play a critical role in the teaching and learning process which culminates in the achievement of overall objectives of education. School principals are aware of this notion and it is the driving force in their day to day operations. This is much more so in with the realization that teaching is one of the noblest professions, because it shapes the socio-economic activities of a country by shaping the future of the child as it unleashes and actualizes the child's potential. To many teachers and principals alike teaching is a very fulfilling and rewarding profession. This is normally as a result of the students' success in their lives which becomes a source of dignity, reverence and satisfaction for principals. However when students' fail to succeed, it becomes a source of frustrations, demeaning and despair for principals. Whichever way, the outcome either creates threats and /or more demands on the principal which affects his /her level of stress.

Factors that influence female principals levels of stress in public secondary schools were found to be 
many. These factors or stressors included; Role conflict, professional development opportunities, undisciplined teachers, political interference, national examination results, time, shortage of staff, sexual harassment, communication, sponsors, managers, promotion, privacy, school funds and students enrolment. These findings concur with those of Sultana et al (2012) who in their study titled "The nature and impact of teacher stress in the private schools of Gilgit -Baltistan, Pakistan "revealed that the teaching profession is challenging in both its intellectual and physical dimensions: Intellectually, the profession requires teachers to constantly enhance and reshape their knowledge and physically, because it requires them to be always dynamic proactive and smart. For the female school principals there are huge responsibilities and the deep -rooted sense of accountability. This arises from the fact that in girls' secondary schools and mixed secondary schools principals' role is complicated, and the threats and demands surpasses those in boys secondary schools. Moreover female principals play dual roles as school administrators and surrogate mothers to the students.

Participatory management puts high demands on the principal. For instance she is expected to prepare lesson plans and show punctuality and regularity in her duties. This fact coupled with the commonplace teacher shortage makes school principalship stressful. The impact of this factor was 3.03 meaning that it moderately influenced stress among female principals. This finding concurs with that of Kousar, Dogar, Ghazal and Khattak (2006) in a study titled "Occupational stress and job performance" in which they found that supervisors and managers can be major sources of stress to their subordinates. This means it is their seniors who cause them stress in the same vein as their participatory management stresses their subordinates. Furthermore when employees refuse to participate in decision making stress is caused to the management.

Work environment was established to have an influence on female principals stress. The mean rating of 3.67 meant that work environment had a high influence. This finding agrees with that of Kousar, Dogar, Ghazal and Khattak (2006) who in their study found that dangerous tasks, toxic chemicals, high noise levels, dust, overcooling unpleasant odours created stress. These factors have a multiplier effect and affect the health of the principal which in turn become major stressors. This view is supported by Gebrekirstos (2015) who in an empirical study titled "occupational stress among secondary school teachers and their coping strategies: The case of Central zone of Tigray region, Ethiopia who established that student had indicated that the growing health complications of workers was due to occupational stress. The consequence of occupational stress is that it impairs not only the health of the employed individuals but also for the society in general by declining effect on the amount of quality work and productivity when its level is high. Due to this reason, occupational stress costs employers as much as $\$ 200$ billion per year globally and consequently this issue of occupational stress among secondary school teachers has been recognized as a devastating problem in many countries of the world. For instance a study conducted in Hong Kong in primary and secondary school teachers showed that considerable number of teachers develop anxiety and depression problems in their work place (Leunga, Makb, Chuic, Chianga and Leea, 2009). The other factor that influence female principals stress level is role conflict, mainly the female principal as a student counselor and a disciplinarian. The study established that the influence was moderate as the mean rating was 3.30. This factor stresses principals to the extent that some principals have delegated these responsibilities absolutely. Being a disciplinarian and a counselor are two extremes on a continuum and that is why it is stressful to operate at bipolar points. Other conflicts are usually due to gender in situation where a couple serves in one school and discipline matter arise. It becomes stressful when it comes to decision making.

Sexual harassment has gained international currency in the $21^{\text {st }}$ Century, whereby politicians and seniors have no respect for female principals with the consequence that gender sexual harassment is traumatizing and this leads to stress. Sexual harassment make female principals become despairing in their profession, and young principals become more affected than their comparable groups.

Fees arrears and untimely disbursement of Free Secondary education funds coupled with parent uncooperativeness are quite stressful to female principals. These stressors coupled with several types of demands such as teaching, preparation of trial balances, excellent students performance and undisciplined students indeed put a lot of pressure on female principals. In fact during the interview, one of the principals stated; This year we have experienced many tremendous frustrations in our attempt to implement the school curriculum and cocurriculum plans. Female principals have found themselves fighting for their subjects, trying to deal with micromanaging some departments where heads of department are less committed. In fact for most female principals, roles seem to have changed. In addition, they have had also to deal with anxiety in their offices. Parttime teachers are quite unpredictable, and paying them is another matter altogether. The lack of consultation and discussion by senior management in the Teachers Service commission and the Ministry of Education Science and Technology has added to the frustration felt by many female principals and this is highlighted by a number of principals who seriously consider leaving teaching in fact the principal of school "Y" decided to take early retirement as her way of coping with the stress resulting from her school. Another principal asserted: I 
think that the spontaneity of classroom relationships and the fun-has been displaced by strict organization, targets, appraisals, reports, parental pressure and expectations of teaching and to non-teaching staffs which is a source of stress.

The increased administrative responsibilities are now commonplace for female principals in secondary schools. In fact management of a secondary school has important dimensions that are major sources of stress. The difficult behaviour, indifferent attitudes and feigned incompetence of staff create considerable problems for female principals, particularly if there is lack of time to keep a careful check on what every staff member is teaching. Serious problems are bound to and do arise when the school is mainly composed of young novice teachers who need a lot of guidance, especially when most of them are presenting students for the first time for national examinations. The teachers, young and old who fail to be disciplined in their classes, who are inept in academic professional know how, or are the subjects of complaints by students, colleagues, parents and nonteaching staff are stressful. Lack of initiative, innovativeness, creativity, accountability and ambition in some staff, their lack of cooperation, lack of effort and resistance to change are responsible for the development of high levels of frustration. Staff turnover, absenteeism, negligence and lateness are other stressors to the female principals.

The job of principalship by female teachers is more stressful in cases where they have very limited number of experienced teachers; say one out of four who is experienced and committed to teaching as the case was in Rachuonyo North and Suba Sub County. The Constituency Development Fund established schools have as few teachers as two, the principal and her deputy, the rest, about three who are Board of Management employees. The implication is that the workload is unmanageable. The problem is compounded by the fact that when one or more teachers leave on promotion, securing their replacement is a nightmare.

In addition to these problems the female principals have to learn and acquire competencies in mediation, diplomacy, balancing the books, coping with professional challenges and extraneous matters. Female principals experience other kinds of problems in their day-to-day dealings with school management Boards, County Directors of Education and other Senior Officers from the Ministry of Education Science and Technology. The leadership behaviour was indicated by informants as a major source of stress. Serious difficulties are caused by facets of senior management styles including their reluctance to delegate any responsibility for decisionmaking, lack of communication between them and their middle management, failure to appreciate the needs of individual schools, low allocation of free secondary education funds and staffing, failure to provide clear roles of newly appointed staff besides teaching, inability to provide clear style of decision-making, appointment and posting of teachers without consultation, introduction of significant changes in school levies without participation of principals, deciding on term dates without reference to principals and "whittling away" of a school because of other principals' negative opinion about the school were found to be great stressed to female principals.

\section{CONCLUSION}

Role conflict, lack of career development opportunities, lack of privacy, political interference, increased participatory management, increased use of ICT, lack of office space, sexual harassment, and inadequate support from stakeholders, poor communication and lack of opportunity for promotion had a moderate influence on female principals stress. Moderate stress positively influences performance; therefore notwithstanding the negative effect it hardly deters performance. This is because the female principals strive to prove that they are equal to the task despite the difficulties they face. Working environment, undisciplined teachers, pursuit for excellence, conflicting demands from stakeholders, lack of time to teach and administer, staff shortage, work load and uncertainty in job expectations had high influence on stress among female principals'. Overall, descriptive statistics analysis revealed that these factors had moderate influence on female principals' stress.

Inferential statistical analysis output revealed that the factors under study had a high influence on female principals' stress which concurred with the descriptive statistics analysis output. The factors explained $52.9 \%$ of female principals' stress. The other $47.1 \%$ was due to other factors that were not investigated. This means that there are many other factors that influence female principals' stress that were not captured by this study. These factors were also established as significant predictors of female principals' stress levels.

\section{RECOMMENDATIONS}

Female principals' stress should be managed by addressing the identified factors effectively. To do this the female principal should remind herself that the stress experienced is both internally and externally generated.

The principal should look at a school as her business. The basic supplies must be guaranteed and availed. Simple items like paper, folders, pens, binders should be well supplied as this would greatly reduce stress among female principals.

The in-tray and out-tray should be clean as it enhances time management for retrieval of documents and information, which in -turn reduces stress among female principals.

Principals should delegate duties and responsibilities 
to suitable staff members. This reduces overwork and frustrations when infractions are experienced. Delegation also leaves the principal with duties and responsibilities that are unique and therefore ordinary ones are sorted out easily with ease.

The principals should be innovative and creative because most factors do not have clear approaches to their solutions. For instance time management is always an individual initiative and is anchored in individual organizational skills which reduce frustration and stress.

The issues of space, staff shortage, workload and role conflicts are best dealt with through benchmarking with successful principals and face-to-face approach with personnel who are charged with the responsibility of dealing with such matters.

\section{REFERENCES}

Abouserie R (1996). Stress, Coping and Job satisfaction in University Academic Life. Educational Psychology.

Adams JD (1980). Improving Stress Management: An Action Research Based OD intervention. Understanding and Managing stress. A book of Readings. University Associates, San Diego, California.

Ajayi K (1995). Reflections on the Nigerian Education System: A college Provosts' perspective. ljebu Ode, Nigeria: Jimmy Press.

Anderson ES, Coffey SB, Byerly TR (2002). Formal organization initiatives and informal Workplace Practices: Links to work-family Conflict and Job related outcomes. J. of Management 2(8):787.

Antonio AS, Polychrnoni F, Vlachaki AN (2006). Gender and age differences in occupational stress and professional burnout between primary and high school teachers in Greece. Journal of Managerial Psychology, 2 Vol. (1)7: 682-692.

Beehr TA (1976). Perceived situational Moderators of the Relationship between subjective Role Ambiguity and Role strain. J. of Applied Psychology Vol. 6(1): 35-40.

Bennel P, Akyeampong K (2007).Teacher Motivation in Sub-Saharan Africa and South Asia. New York: DFID Department of International Development.

Bennet, N. and Cass, A. (1998). From Special to ordinary school. Case studies in integration. London: Cassel Educational Limited.

Borg MG (1991). Stress in Teaching: A study of occupational stress and its determinants. Job satisfaction and career commitment among secondary school teachers."Educational Psychology, Vol. 1.

Boyland L (2011). Job Stress and Coping strategies of elementary principals: A statewide study. Current Issues in Education, 114(3):111 retrieved

from http:cie.asu.edu/ojs/index.php/cieatasu/article/view/806.

Bull C (2013). The Research Project: How to write it. New York.

Bunce D, West MA (1996). Stress Management and Innovative Interventions at work. Human relations, 49(2): 209-32.

Chandolla T, Brunner E, Marmot M (2006). Chronic stress at work and the metabolic syndrome: A prospective Study. London: Br Med J: 332:521-524.

Chaplain RP (2001). Stress and Job Satisfaction among primary head teachers: A question of balance? 197-215. London: Education Management Administration.

Cohen L, Manion L, Morrison K (2007).Research Methods in Education. London: Routledge Tylors and Francis.

Cook CW, Hunsaker PL (2001). Management and Organizational Behavior (3rd edition).Retrieved from http:// Karlknapp.com/resources/management/mgt300booksummary.doc on 6/10/2014 at 9.00pam.

Creswell JW (2005). Educational Research: Planning, Conducting and Evaluating Quantitative and Qualitative Res.. New Jersey: Pearson Prentice Hall.
Crossman A, Harris P (2006). Job Satisfaction of secondary school teachers. Educational Managt. and Leadership, Vol. 34 (1): 29-46.

Daily Nation Paper (2014a, June $27^{\text {th }}$ ). Poor -results tutors ordered back to class. Daily Nation. Nairobi: Nation Media Group. P. 6.

Daily Nation Paper (2014b, June $\left.27^{\text {th }}\right)$. Sexual abuse in schools worries TSC. Daily Nation. Nairobi: Nation Media Group. P. 6.

Daily Nation Paper (2014c, June $27^{\text {th }}$ ). Thirty nine pieces of teachers missing class Daily Nation: Nairobi; Nation Media Group. P. 6.

De Nobile JJ, Mc Cormick J (2005). Job satisfaction and occupational stress in Catholic Primary schools. Paper presented at the Annual conference on the Australian Association for research in education. Sydney: Australia.

Dollard MF (2003). Occupational Stress in the Service professions, New York: Taylor and Francis.

Educational Research Service. (1999). Professional Development for school principals. The informed Educator Series.

Fisher MH (2011). Factors influencing Stress, Burnout, and Retention of Secondary Teachers. Current Issues in Education, 14(1). Retrieved from http://cie.asu.edu.

Fontana D (1989). Managing Stress. London: The British Psychological Society and Routledge.

Forlin C (2001). Inclusion: Identifying potential stressors for regular class teachers. Edu. Res, 43(3): 235-245.

Friedman I (1997). High and Low burnout principals: What makes the difference? ERIC Document Number ED410685.

Gebrekirtos HA (2015). Occupational Stress among Secondary School Teachers and their Coping Strategies: The Case of Central zone of Tigray Region. Intl. J. of Academic Res. in Edu. and Review. Vol 3(6): 143-157. Ethiopia.

Gonzalez MA (1997). A Study of the relationship of stress, Burnout, hardiness and social support in urban secondary school teachers. Unpublished PhD Thesis, Layola, University of Chicago. Dissertations Abstracts International. Vol. 57 No. 2

Green, F. (2000). The Head teacher in the $21^{\text {st }}$ Century. Being a successful school leader. London: Pearson Education.

Greenhaus JH, Beutell N (1985). Working Hours, Work-family Conflict and Work-family Enrichment among Professional Women: A Malaysian Case. 2011 International Conference on Social Science and Humanity. Vol.5: 1-4. IACSIT Press, Singapore.

Greenhaus JH, Beutell N (1985). Sources of conflict between work and family roles. Academy of Management Review, 10: 76-88.

Guglielmi RS, Tatrow K (1998).Occupational stress, burnout and health in teachers: A Methodological and theoretical analysis. Review of Edu. Res. 17(1): 39-52.

Hall K, Savery LK (1986). Tight Rein, More stress. Harvard Business Review 23(10): 1162-1164.

Hoyle E (1989). The study of schools as organizations. Management in Education: The Management of Organizations and individuals. Ward Lock Education /Open University.

Hughes RE (2001). Deciding to leave but saying: Teacher burnout, precursors and turnover. Intl. J. of Human Resource Manag.12(2): 288-98.

Ivancevic JM, Gilbert JA, Stead BA (1999). A new organizational paradigm. J. of Business Ethics; Res. Library Vol. 21 (1):1-16.

Johnson S, Copper C, Cartwright S, Donald I, Taylor P, Millet C (2005). The Experience of Work related stress across occupants. New York: J Manage Psycho.

Karasek RA, Theorell T (1990). Healthy Work. Stress Productivity and Reconstruction of working life. New York. Basic books.

Kelly MJ (1991). Occupational Stress among Principals /Director of Public sector educational establishments in the UK. Manchester: UMIST.

Kendi RS (2012). Impact of Occupational stress on head teachers tasks in secondary schools of Kisumu County, Kenya. A Research project submitted for the degree of Master of Education in the School of Educational Management, policy and curriculum studies of Kenyatta University Kenya.

Kenya Secondary School Heads Association (2014). The Principal. Secondary School Magazine. Nairobi.

Kenya Secondary School Heads Association Conference (2014). Proceedings at KESSHA Conference held at Mombasa, Kenya. 
Koech SJ, Tikoko BJ, Bernard C, Chemwei B (2014). Institutional Factors that influence teacher turnover in public secondary schools in Baringo District.

Koome IN (2007). The Exodus of Principals Teacher Management Issues in East Africa. UNESCO Africa. 17 (10): 6.

Kousar S, Dogar IA, Ghazal S, Khatak AK (2006). Occupational Stress and Job Performance. Intl. J. of academic res. in progressive edu. and development. 1(2):64-84

Kothari CR (2003). Research Methodology: Methods and Techniques. Wishwa Prakashian. New Delhi.

Kyrianacou C, Kunc R, Stephens P, Hutren A (1999). Student teachers motivation to become secondary school teacher in England and Norway. Educational Review, 55: 255-263.

Lait J, Wallace JE (2002). Stress at work: A study of organizational professional conflict and unmet expectations. Relations Industrielles, 57(3):463-487.

Leunga SS, Makb YW, Chuic YY, Chianga VC, Leea AC (2009). Occupational Stress, Mental Health Status and Stress management behaviours among secondary school teachers in Hong Kong. Health Edu. J. 68(4):328-343.

Levi L (1987). Occupational Stressors, Biological stress and workers Health. J. of the University of occupational and environmental Health. (Kitakyuushu, Japan Vol. 11:229-245.

Mac Pherson MA (1985). Burnout and the School Principal, Canadian Administrator, Vol. 2(5): 1-4.

Martha D, Elizabeth RE, Matthew M (1988). Relaxation and Stress Reduction Workbook. Oakland: New Haerbinger publications, Inc.

Mbua FN (2003). Educational administration: Theory and Practice. Limbe, South West Province, Cameroon: Design House.

Mugenda OM, Mugenda AG (2003). Research Methods: Quantitative and Qualitative Approaches, Nairobi. ACTS Press.

Murray TJ, Forbes D (1986). Where have all the middle managers gone? Dun's Business month, 31-34.

Musyoka M, Ogutu M, Awino ZB (2012). Employee Stress and Performance of Companies listed in the Nairobi Securities Exchange. DBA Africa Management review 2012, Vol. 3 (1):115129.

Nhundu T (1999). Determinants and Prevalence of occupational stress among Zimbabwean school Administrators. New York: Education Administration. J. of Educational Administration Vol.3 (7):256-272.

Ngari SM, Ndungu A, Mwonya R, Ngumi O, Mumiukha C, Chepchieng M, Kariuki M (2013). Levels of Stress among secondary school administrators and its implication in education management in Kenya. Educational Research and Reviews 8(11)671.

Nkapa N (1997). Educational Res. for Modern Scholars. Lagos. $4^{\text {th }}$ Edition. Dimension Pub.

Nilleepa N (1997). Educational Research for modern scholars. Lagos: Fourth Dimension publisher.

Orodho JA (2004). Elements of Education and Social Research methods. Mosola publishers. Nairobi, Kenya.

Ostell A, Oakland S (1995). Head teacher stress, coping and health. Aldershot: Avebury.

Phillips S, Sen D, McNamee R (2008). Risk factors for work related stress and health in head teachers Occupational Med. (London) 58(8).

Pithers R, Sohen R (2002).Gender and Age as moderators of the relationship between efficacy of vocational teachers' personal resources and strain. Australian and New Zealand J. of Vocational Edu. Res.. 10(2): 45-68.

Poornima R (2010). Emotional Intelligence, Occupational Stress and Job satisfaction of Special Education Teachers. P.hD thesis Dept. of Education, Dravidian University, Kuppam.

Quarles HR (1996).Burnout in heads of Independent schools in Southern California, Unpublished PhD Thesis. Dissertations Abstracts International, Vol. 57, No. 7.
Reddy GL (2011) Occupational stress, professional Burnout and job satisfaction of university teachers in South India, UGC major research project, hD thesis Dept. of Education, Dravidian University, Kuppam.

Robbins SP, Coulter M, Vohra N (2010). Management.10 $0^{\text {th }}$ Edition. Pearson Prentice Hall, India.

Robbins, S.P. (2001). Organizational Stressors and Job Stress Among Managers: The

Moderating Role of Neuroticism. J. Article. Retrieved from ramayah.com/journalarticlespdf/organizationalstressors.pdf

Seyle H (1984). The Stress of Life. New York. McGraw Hill Books Company.

Shann MH (2001). Professional Commitment and Satisfaction among teachers in urban middle schools. The J. of Edu. Res. 92 No. 2: 6773.

Schiller J (2002). Teaching principals in smaller primary schools: Their issues, challenges and concerns AARE Conference.

Schroeder RM, Akatia CS, Apekey AK (2001). Stress and Coping among Ghanaian School Teachers, Ife Psychologia: An Intl. J. Vol. 9(1): 89-98.

Sodoma B, Else D (2009).Job satisfaction of lower public school principals. The Rural Educator, Vol. 31(1): 10-18.

Stamper LC, Johlke CM (2003). The Impact of Perceived Organizational support on the Relationship between Boundary Spanner, role, stress and work outcome. J. of Management. Vol. 2(9): 569.

Siddiqui FA (2012). Occupational Stress in Teachers: A comparative study of public and Private schools in Hyderabad City. J. of Edu. Vol. 42 Issue 13:62-73.

Sulatana B, Bano F, Sherfa MD (2012). The Nature and Impact of Teacher Stress in the Private Schools of Gilgit -Baltstan, Pakistan. J. of Pakistan Psychiatric Society. 3(2):93-97.

Taylor ES (1995). Health Psychology. New York: McGraw Hill, Inc.

Tatar M, Yahav V (1999).Secondary School Pupil's perceptions of Burnout among teachers. British J. of Edu. Psychology 69:457-68.

Teachers Service Commission (2005). TSC Code of Regulations. Nairobi TSC.

Thomas N, Clarke V, Lvery J (2003). Self reported work and family stress of teachers. Australian J. of Edu. 47(1): 73-88.

Travers CJ, Cooper CL (1994). Mental Health, Job Satisfaction and Occupational Stress among UK Teachers, Work and Stress. Vol. 7(3): 205-219.

Von Onciul (1996). ABC of work Related Disorders: Stress at Work. Retrieved on 6/11/2014 from www.bmj.com/content/313/7059/745 $10.30 \mathrm{~m}$.

Witte DH (2007). Testing Karaseks learning and strain hypotheses on young workers in their job. Works and Stress. 21(2): 131-141. Retrieved on the $2^{\text {nd }}$ of April, 2008 from URL:http://dox.doi.org/10. 1080/026783707014005866.

Woods AM, Weasmer (2002). Maintaining job satisfaction: Engaging professionals as active participants. The Clearing House. 75: 186189.

World Bank (1999). Secondary Education. Washington. The Intl. Bank of reconstruction and development.

Yambo JMO, Kindiki JN, Tuitoek JKF (2012). Investigating High School Principals' Stress in Relation to their job experience in schools in Southern Nyanza/Region of Kenya International J. of Academic Res. in Progressive Edu. and Development, Vol. 1 (4): 44-63. 